\title{
First case of Fanconi-Bickel syndrome genetically diagnosed in Sri Lanka
}

\author{
M S T Guruge ${ }^{1}$, D S Wijesekara ${ }^{2}, * V$ P Sinhabahu ${ }^{3}$, M H M Nazmy ${ }^{1}$, J Hettiarachchi ${ }^{1}$
}

Sri Lanka Journal of Child Health, 2019; 48(2): 176-178

DOI: http://dx.doi.org/10.4038/sljch.v48i2.8718

(Key words: Fanconi-Bickel syndrome, Sri Lanka)

\section{Introduction}

Fanconi-Bickel syndrome (FBS) was first described in 1949 in a Swiss boy who was followed up over five decades ${ }^{1}$. Less than 200 FBS patients have been reported in the literature ${ }^{2-5}$. Extensive literature survey did not show any cases of FBS in Sri Lanka. We present the first case of FBS with genetic diagnosis in Sri Lanka.

\section{Case report}

An eleven month old boy, third child of second degree consanguineous healthy parents, presented with progressive abdominal distension since birth. He did not have recurrent infections. Two elder brothers are healthy. He was exclusively breast fed up till six months with poor complementary feeding practices since then. His first cousin who was also born to consanguineous parents died at eighteen months of age following a similar disease course which was not investigated.

Anthropometry showed a length of $65 \mathrm{~cm}(<-3 \mathrm{SD})$, a weight $6.85 \mathrm{~kg}(-3 \mathrm{SD})$ and an occipito-frontal circumference of $44 \mathrm{~cm}\left(5^{\text {th }}\right.$ centile). He had a 'doll like face', mild pallor, hepatomegaly and features of rickets such as frontal bossing, widened wrists and rachitic rosary (Figure 1).

\footnotetext{
${ }^{1}$ Registrar in Paediatrics, ${ }^{2}$ Senior Lecturer and Consultant Paediatric Neurologist, ${ }^{3}$ Senior Registrar in Paediatrics, Professorial Paediatric Unit, Colombo South Teaching Hospital, Sri Lanka

\section{*Correspondence: sinbad.1k@gmail.com}

D https://orcid.org/0000-0003-0065-2845

(Received on 23 June 2017: Accepted after revision on 18 August 2017)

The authors declare that there are no conflicts of interest Personal funding was used for the project.
}

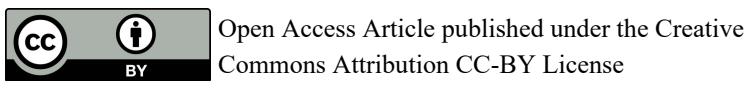

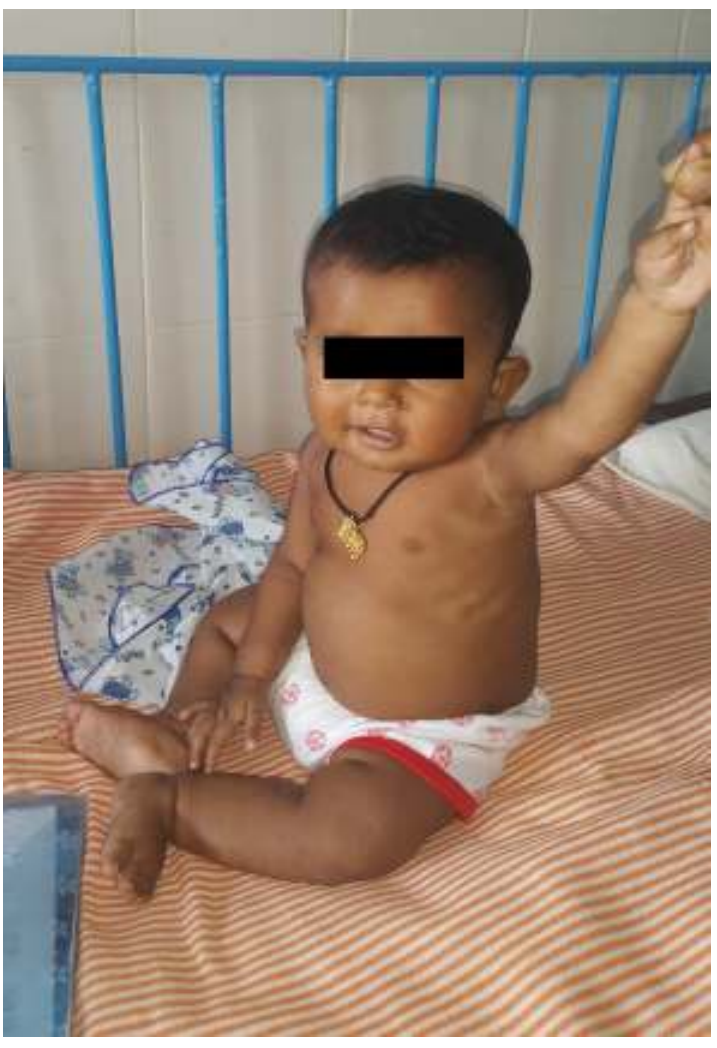

Figure 1: The patient

Liver was palpated $4 \mathrm{~cm}$ below costal margin. Spleen and kidneys were not palpable. Development assessment revealed gross motor delay with age appropriate fine motor, speech and social development.

He had fasting hypoglycaemia (capillary blood sugar $38 \mathrm{mg} / \mathrm{dl}$ with four hour fasting), positive urinary ketone bodies and glycosuria. Urinary reducing substances were positive. Guthrie test was positive for galactosaemia. His serum triglyceride level was 352 $\mathrm{mg} / \mathrm{dl}$ (normal $<99 \mathrm{mg} / \mathrm{dl}$ ) Serum uric acid level was $39 \mathrm{micromol} / 1$ (normal 119-327micromol/1). Blood gas analysis showed metabolic acidosis with a normal anion gap (7-16 mmol/l) as shown in Table 1. 
Table 1: Venous blood gas and serum electrolytes

\begin{tabular}{|l|l|}
\hline \multicolumn{1}{|c|}{$\begin{array}{c}\text { Venous blood gas and } \\
\text { serum electrolytes }\end{array}$} & \multicolumn{1}{c|}{ Result } \\
\hline $\mathrm{pH}$ & 7.3 \\
\hline $\mathrm{pCO}_{2}$ & $38 \mathrm{mmHg}$ \\
\hline $\mathrm{HCO}_{3}$ & $18.5 \mathrm{mmol} / 1$ \\
\hline Base excess & $-5.7 \mathrm{mmol} / 1$ \\
\hline Serum sodium & $140 \mathrm{mmol} / \mathrm{l}$ \\
\hline Serum potassium & $4.2 \mathrm{mmol} / 1$ \\
\hline Serum chloride & $109 \mathrm{mmol} / \mathrm{l}$ \\
\hline Anion gap & $12.5 \mathrm{mmol} / 1$ \\
\hline
\end{tabular}

His blood amino acid and acyl carnitine profiles were normal. Caeruloplasmin level was 539 U/1 (normal 330-430 U/1). Clotting profile was normal. Ultrasound scan of abdomen showed a prominent liver of $9.5 \mathrm{~cm}$ with normal spleen and kidneys. Plain radiographs of chest and wrist showed features of rickets. (Figure 2). His serum corrected calcium level was $2.75 \mathrm{mmol} / 1$ (normal 2.2-2.7), phosphate $0.98 \mathrm{mmol} / \mathrm{l}$ (normal 1.45-2.16) and alkaline phosphatase $2249.6 \mathrm{U} / 1$ (normal 110-320) which was compatible with hypophosphataemic rickets.

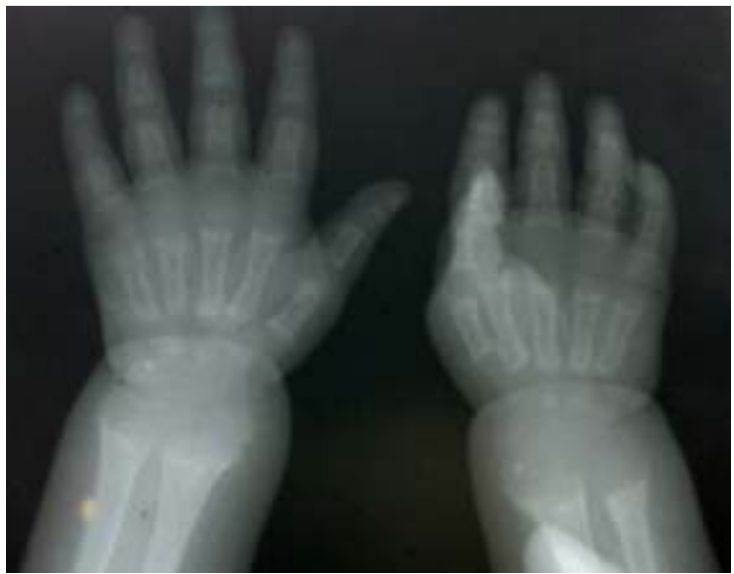

Figure 2: Radiograph of both hands

Urine analysis showed a $\mathrm{pH}$ of 6.5 , no cells or casts, protein ++ , Clinitest - yellow and Clinistix - ++++. Further analysis of spot urine sample showed urinary loss of electrolytes, phosphates, and proteins (Table 2).

Table 2: Spot urine sample results

\begin{tabular}{|l|c|c|}
\hline \multicolumn{1}{|c|}{ Investigation } & Value & Normal range \\
\hline Urinary $\mathrm{Na}^{+}(\mathrm{mmol} / \mathrm{l})$ & 43.7 & $<20$ \\
\hline Urinary $\mathrm{K}^{+}(\mathrm{mmol} / \mathrm{l})$ & 22 & $<20$ \\
\hline Protein/creatinine ratio (mg/micromoles) & 679 & $0.09-2.2$ \\
\hline Calcium/creatinine ratio (mmol/micromoles) & 2.52 & $1.2-19$ \\
\hline Phosphate/creatinine ratio (mmol/micromoles) & 8.0 & $15-20$ \\
\hline Fractional excretion of phosphate & 24.51 & $0.4-2.2$ \\
\hline Magnesium /creatinine ratio (mmol/micromoles) & 2.42 & \\
\hline
\end{tabular}

Bilateral posterior capsular cataracts and mild concentric left ventricular hypertrophy were found on ophthalmoscopy and 2D echocardiography respectively. Liver biopsy revealed preserved architecture. Hepatocytes were enlarged with empty vacuolated cytoplasm, small pyknotic nuclei and thickened cell membranes. Portal tracts were normal without significant peri-cellular or peri-sinusoidal fibrosis or cholestasis. Although routine histology favoured glycogen storage disease (GSD), glycogen was not demonstrated by PAS/PASD stain. Analysis of all coding regions and exon/intron boundaries of the SLC2A2 gene by Sanger sequencing showed homozygosity for a SLC2A2 splicing mutation, c. $963+1 \mathrm{G}>\mathrm{T}$. which confirmed the diagnosis of FBS. Both parents were heterozygous.

\section{Discussion}

FBS (OMIM 227810) is an autosomal recessive disorder due to a defect in SLC2A2 gene which codes for GLUT $2^{6}$. The defective GLUT 2 receptors in the renal tubules, hepatocytes and pancreas lead to symptoms due to defective glycogen storage, glucose and galactose metabolism and renal tubular dysfunction $^{2}$. Clinical features include hepatomegaly, hypophosphataemic rickets, fasting hypoglycaemia, failure to thrive and proximal renal tubular acidosis with renal Fanconi syndrome which is evidenced by glycosuria, aminoaciduria, phosphaturia, bicarbonate loss and hypophosphataemia ${ }^{2,3}$. Currently patient is being managed symptomatically. The prognosis of the disorder is unknown ${ }^{6}$. Short stature is known to occur ${ }^{1}$. Both parents were found to be carriers. The cause of death of the child's cousin remains unanswered.

\section{Acknowledgements}

We thank the Molecular Genetics Laboratory, the Medical School of University of Exter, for carrying out the genetic testing for our patient, Dr. Eresha Jasinghe, Consultant Chemical pathologist, Dr. Dulani 
Benaragama and Dr. C. S. Perera, Consultant Histopathologists, for the support given in investigating the patient.

\section{References}

1. Santer R, Schneppenheim R, Suter $\mathrm{D}$, Schaub J, Steinmann B. FanconiBickel syndrome--the original patient and his natural history, historical steps leading to the primary defect, and a review of the literature. European Journal of Pediatrics. 1998; 157(10):783-97. https://doi.org/10.1007/s004310050937 PMid: 9809815

2. Kehar M, Bijarnia S, Ellard S et al. FanconiBickel syndrome - Mutation in SLC2A2 Gene. Indian Journal of Pediatrics 2014. 81(11):1237-9

3. Setoodeh A, Rabbani A. Transient neonatal diabetes as a presentation of Fanconi-Bickel Syndrome. Acta Medica Iranica, 2012; 50(12): 836-8.

PMid: 23456528

4. Afroze B, Chen M. FanconiBickel syndrome: Two Pakistani patients presenting with hypophosphataemic rickets.
Journal of Pediatric Genetics 2016; 5(3): 161-6.

https://doi.org/10.1055/s-0036-1584360

PMid: 27617158

5. Dweikat IM, Alawneh IS, Bahar SF, Sultan MI. Fanconi-Bickel syndrome in two Palestinian children: marked phenotypic variability with identical mutation. $B M C$ Research Notes 2016. 9:387 https://doi.org/10.1186/s13104-016-2184-2 PMid: 27487919 PMCid: PMC4973067

6. Valla Dominique-Charles. Fanconi Bickel syndrome. Available from:

http://www.orpha.net/consor/cgibin/Disease Search.php?lng=EN\&data id=3513\&Disea se_Disease_Search_diseaseGroup=fanconibi ckelsyndrome\&Disease_Disease_Search_dis easeType $=$ Pat $\&$ Disease $(\mathrm{s}) /$ group $\% 20$ of $\% 20$ diseases $=$ Glycogen-storage-disease-due-toGLUT2-deficiency\&title=Glycogenstorage-disease-due-to-GLUT2deficiency\&search=Disease_Search_Simple. Viewed on 2017.03.10 